\title{
Effect of De-Oiled Oil Palm Kernel Meal Based Biofloc System on Growth and Digestive Enzyme Activity of Pacific White Shrimp, Litopenaeus Vannamei
}

\author{
Karthireddy Syamala $^{1 *}$, W.S. Lakra ${ }^{2}$, N.K. Chadha ${ }^{3}$, N.P. Sahu ${ }^{4}$ and K. Pani Prasad ${ }^{5}$ \\ ${ }^{1}$ ICAR-Central Institute of Fisheries Education, Kakinada centre, Kakinada, \\ Andhra Pradesh-533001, India \\ ${ }^{2}$ OSD Blue Revolution, ${ }^{3}$ Division of Aquaculture, ICAR-Central Institute of Fisheries Education, \\ PanchMarg, Yari Road, Andheri (w), Mumbai, Maharashtra-400 061, India \\ ${ }^{4}$ Fish Nutrition, Biochemistry and Physiology Division, ${ }^{5}$ Aquatic Environment and Health \\ Management Division, ICAR-Central Institute of Fisheries Education, PanchMarg, Yari Road, \\ Andheri (w), Mumbai, Maharashtra-400 061, India \\ *Corresponding author
}

\section{A B S T R A C T}

Keywords

Oil palm kernel meal, Biofloc, Shrimp, FCR, Protease, Amylase

Article Info

Accepted:

23 May 2017

Available Online:

10 June 2017
A 40-day experiment was conducted to study the effect of de-oiled oil palm kernel meal based biofloc system on growth performance and digestive enzyme activity of Litopenaeus vannamei. Juveniles of $L$. vannamei with an average weight of $(0.82 \pm 0.02 \mathrm{~g})$ were stocked in tanks with a water volume of $150 \mathrm{~L}$ at a stocking density of $300 \mathrm{PL} \mathrm{m}^{-3}$. Highest weight gain percentage (519.05 \pm 9.52$)$, protein efficiency ratio $(1.78 \pm 0.02)$ and survival rate $(88.67 \pm 0.88)$ were observed in oil palm kernel meal based biofloc treatment. Lowest FCR value $(1.61 \pm 0.02)$ has been recorded in biofloc treatment. Although the digestive enzymes had not shown any significant difference, a slight increase in the protease and amylase activities have been observed in biofloc treatment. So the present study suggests that non-conventional carbon source - de-oiled oil palm kernel meal can be utilized for the development of biofloc.

\section{Introduction}

Limitation of aquaculture expansion area has given rise to the concept of aquaculture intensification. The major setback of the aquaculture intensification is the accumulation of nitrogenous wastes and environmental pollution which will result in disease condition or death of the farmed animals (Yang and Qiu, 2006; De Schryver and Verstraete, 2009). The concept of aquaculture intensification has raised many environmental and social concerns. Aquaculture development needs the support of aquaculture intensification coupled with resource usage, environmental, social and economic sustainability (Naylor, 2000; Avnimelech, 2009). Biofloc technology has the capability to meet all the prerequisites as mentioned earlier. 
The Pacific white shrimp Litopenaeus vannamei is the most widely cultivated species in the world. Recently, L. vannamei farming is facing some issues and problems in the culture which needs a serious contemplation. Diseases such as black gill disease, White Spot Syndrome Virus (WSSV), Infectious Hypodermal Hematopoietic Necrosis Virus (IHHNV), MonodonBaculo Virus (MBV), White muscle disease, White gut disease, Muscle cramp syndrome, Runt Deformity Syndrome (RDS), Early Mortality Syndrome (EMS) and Enterocytozoon hepatopenaei (EHP) associated with severe growth retardation have been reported in L. vannamei (Lightner et al., 2012; Gunalan et al., 2014; Newman, 2015). In addition to the disease problems, other issues like limited quarantine facilities, production cost towards feed, quality seed availability, feed quality and availability and environmental impact and management are also affecting the L. vannamei culture in India (Babu et al., 2013).

Extensive studies on the biofloc based nursery and grown out phases of L.vannamei in the recent years had shown improvement in the growth performance, feed utilization and disease resistance (Burford et al., 2004; Hari et al., 2004; Hari et al., 2006; Wasielesky et al., 2006; Samocha et al., 2007; Ju et al., 2008a; Kuhn et al., 2008; Xu et al., 2012, 2013). The carbon sources most widely used for biofloc are molasses, cassava, wheat flour, sorghum, corn flour, starch, glucose, cellulose and dextrose (Emerenciano et al., 2013). However, all these carbon sources already have potential value and application in other aspects which question their usage in the biofloc production (Crab et al., 2012). Given these, new research on biofloc production using the low-cost non-conventional carbon sources from agro-industrial residues is very essential. Utilization of non-conventional carbon sources for biofloc production can convert these agro-industrial wastes into the nutritious feed (Crab et al., 2012; Caipang et al., 2015; Ahmad et al., 2017).

The present study evaluated the use of nonconventional carbon source, de-oiled oil palm kernel meal (Elaeis guineensis), which is a low-cost palm oil industry waste for biofloc production. The effects of de-oiled oil palm kernel meal on water quality, growth and digestive enzyme activity of $L$. vannamei were studied to assess the viability of this carbon source in biofloc systems.

\section{Materials and Methods}

\section{Experimental design and rearing}

The present study was carried out at the Brackish water Fish Farm of Central Institute of Fisheries Education, Kakinada Centre, Kakinada, East Godavari District, Andhra Pradesh, India. An experiment of 40 days with one control (clear water system) and one treatment (oil palm kernel meal based biofloc) with three replicates each following completely randomized design (CRD) was conducted. L. vannamei juveniles with an average weight of $(0.82 \pm 0.02 \mathrm{~g})$ were stocked in fibre reinforced plastics (FRP) tanks with a water volume of $150 \mathrm{~L}$ at a stocking density of $300 \mathrm{PL} \mathrm{m}{ }^{-3}$.

The shrimps were fed at $5 \%$ of body weight thrice a day (07.00 hrs $12.00 \mathrm{hrs}$ and 17.00 hrs) with a commercial pellet feed (35\% crude protein; $5 \%$ lipid; $25 \%$ carbohydrate). The feed was adjusted according to the changes in the biomass during the experimental period. The control tanks were fed with only commercial feed whereas the biofloc treatment tanks were supplied with both feed and carbon source. No water exchange was carried out in biofloc treatment tanks. 
Preparation of biofloc and carbon source addition

The carbon source used in the present study, Oil palm kernel meal was obtained from Ruchi soya industries limited, palm oil division at Peddapuram, East Godavari District, Andhra Pradesh, India. Avnimelech (1999) methodology with $20 \mathrm{~g} \mathrm{~L}^{-1}$ pond soil, $10 \mathrm{mg} \mathrm{L}^{-1}$ ammonium sulphate, and $400 \mathrm{mg}$ $\mathrm{L}^{-1}$ carbon source was used for the preparation of biofloc inoculum. The suspension was well aerated for $24 \mathrm{hrs}$ and later mixed into experimental tanks. Oil palm kernel meal was added regularly to maintain a $\mathrm{C}: \mathrm{N}$ ratio of 15:1 following De Schryver et al., (2008). The pre-weighed oil palm kernel meal was mixed with water and uniformly distributed in the biofloc treatment tanks.

\section{Water quality}

Water quality parameters such as salinity, temperature, dissolved oxygen, $\mathrm{pH}$, total alkalinity, total ammonia nitrogen (TAN), nitrite and nitrate were observed and analyzed as per standard procedures (APHA, 1998). Water temperature, $\mathrm{pH}$ and dissolved oxygen were determined daily. Alkalinity, TAN, nitrite and nitrate were estimated weekly twice. Biofloc volume was determined weekly using Imhoff cones after 30 minutes sedimentation (Avnimelech and Kochba, 2009).

\section{Proximate analysis}

The crude protein, ash, crude lipid, fibre and carbohydrate of the carbon source and biofloc were analyzed using standard methods (AOAC, 1995). Biofloc samples were collected water through a $10 \mu \mathrm{m}$ mesh nylon bag (Xu et al., 2012) and were dried in an oven at $105{ }^{\circ} \mathrm{C}$ until constant weight was achieved. Protein, lipid and ash contents were estimated by kjeldahl, soxhlet and muffle furnace methods, respectively. Nitrogen content was evaluated by the Micro-Kjeldahl method (Pearson, 1976) and crude protein level was calculated by multiplying the percentage nitrogen with 6.25. Lipid was determined by acid hydrolysis (Neilsen, 2010). Carbohydrate content was determined by the difference between $100 \%$ and the sum of values of moisture, protein, fibre, lipid and ash. The percentages of the crude protein, ash, crude lipid, fibre and carbohydrate were calculated on dry weight basis of the carbon source and biofloc.

\section{Zootechnical performance}

The growth performance of shrimps, length and weight of the shrimps $(n=30)$ were recorded at a regular interval of 10 days. The parameters evaluated included, Specific Growth Rate $\left(\right.$ SGR, \%/day $\left.{ }^{-1}\right)=[($ ln Final weight $-\ln$ Initial weight) / Number of days] $\mathrm{X}$ 100; Feed Conversion Rate $(\mathrm{FCR})=$ Feed given (dry weight) / Body weight gain (wet weight); Feed Efficiency Ratio (FER) = Body weight gain (wet weight) / Feed given (dry weight); Protein Efficiency Ratio (PER) = Body weight gain (wet weight) / Crude Protein in feed; Survival $(\%)=($ Total number of animal harvested / Total number stocked) $\mathrm{x}$ 100.

\section{Digestive enzyme activity}

At the experiment end, hepatopancreas of shrimps $(n=5)$ were collected from each treatment tank for enzymatic analysis.

A 20\% tissue homogenate of hepatopancreas was prepared with $0.25 \mathrm{M}$ chilled sucrose solution. The tissue solution was homogenized and centrifuged at $8000 \mathrm{rpm}$ for 10 minutes for removal of tissue debris. The supernatant was collected and stored in $-20^{\circ} \mathrm{C}$ until further analysis. 
Amylase activity of samples was determined using the DNS method by measuring the absorbance at 540nm (Bernfeld, 1955). One unit of amylase is defined as micromoles of maltose produced per min at $37{ }^{\circ} \mathrm{C}$. The Protease activity of samples was estimated by casein digestion method, and the final absorbance was measured at $280 \mathrm{~nm}$ (Liu et al., 1991). The protease activity was determined from the tyrosine standard curve, and one unit of protease activity was defined as micromoles of tyrosine released per min per mg protein at $37^{\circ} \mathrm{C}$.

\section{Statistical analysis}

The statistical analysis of growth, digestive and proximate parameters was analyzed by one-way analysis of variance (ANOVA) using SPPS (version - 22.0). Duncan's multiple range tests were used for post hoc comparison of mean $(p<0.05)$ between different groups. All the data presented in the text, figures and tables expressed are mean \pm standard error and statistical significance for the test was set at $p<0.05$.

\section{Results and Discussion}

\section{Water quality}

Water quality parameters observed in the present study are given in table 1 . The water temperature was recorded between $26-28^{\circ} \mathrm{C}$ and had not shown any significant difference (p>0.05) between the treatments. Salinity was observed at $7 \mathrm{ppt}$ and showed no significant difference $(p>0.05)$. Dissolved oxygen had not shown any significant difference $(\mathrm{p}>0.05)$ between treatments and mean DO value was between 5.50-5.57 $\mathrm{mgL}^{-1}$. $\mathrm{pH}$ value varied significantly $(\mathrm{p}<0.05)$ among the treatments and lowest $\mathrm{pH}$ was recorded in biofloc treatment. Alkalinity values had shown significant difference among treatments and the mean ranged from 153.10-161.90 mg
$\mathrm{CaCO}_{3} \mathrm{~L}^{-1}$. A significant difference $(\mathrm{p}>0.05)$ was not observed in the TAN values among the treatments, but the highest TAN value of $1.5 \mathrm{mgL}^{-1}$ was recorded in biofloc treatment. A significant difference $(\mathrm{p}<0.05)$ was recorded in nitrite and nitrate values. The highest nitrite and nitrate values of $2 \mathrm{mg} \mathrm{L}^{-1}$ and $40 \mathrm{mg} \mathrm{L}^{-1}$ were recorded in biofloc treatment.

\section{Proximate analysis}

The proximate analysis of de-oiled oil palm kernel meal and biofloc are given in table 2 . The de-oiled oil palm kernel meal contained $15.58 \%$ crude protein, $6.8 \%$ crude lipid, $3.53 \%$ ash, $30.29 \%$ carbohydrate and $35.83 \%$ fibre. Biofloc comprised of $22.96 \%$ crude protein, $3.8 \%$ crude lipid, $4.7 \%$ ash, $26 \%$ carbohydrate and $14 \%$ fibre.

\section{Zootechnical performance}

The zootechnical performance of L. vannamei recorded at the end of 40 days is given in table 3 .

The initial individual weight has not shown any significant difference $(\mathrm{p}>0.05)$ among the treatments. The final individual weight, specific growth rate, weight gain, feed conversion efficiency and survival rate of the control was significantly lower than the biofloc treatment. The PER and FCR had shown a significant difference $(p<0.05)$ among the treatments and the highest value of PER (1.78 \pm 0.02$)$ and lowest FCR (1.61 \pm 0.02$)$ were recorded in biofloc treatment.

\section{Digestive enzyme activity}

Protease and amylase activities of the treatments are given in figure 1. Although no significant difference ( $p>0.05)$ was observed, slightly higher protease and amylase activities were found in biofloc treatment. 


\section{Water quality}

All the water quality parameters observed in the present study were in the optimum range for L. vannamei culture (Van Wyk and Scarpa 1999; Cohen et al., 2005; Mishra et al., 2008; Fast and Lester, 2013). pH value has shown significant difference among the treatments. The reduction of $\mathrm{pH}$ value in the biofloc treatments may be attributed to the respiration of the microbes in the biofloc and accumulation of carbon dioxide concentration (Wasielesky et al., 2006). Significantly lower alkalinity values were observed in biofloc treatments, which may be due to the oxidation of ammonia into nitrate and respiration of microbes in the heterotrophic system (Ebeling et al., 2006). No significant difference was observed in the TAN values among the treatments. Lesser TAN values in the present study indicate the active nitrification process and the presence of heterotrophic bacteria (Vinatea et al., 2010). Significantly highest nitrate value of $40 \mathrm{mg} \mathrm{L}^{-1}$ was recorded in biofloc treatment. Reduction in TAN, nitrite, alkalinity and accumulation of nitrate in the study indicates the presence of nitrifiers (Cohen et al., 2005; Ebeling et al., 2006). The results of water quality indicate the efficiency of the de-oiled oil palm kernel meal based biofloc system.

\section{Proximate analysis}

Alcohols, sugars, starches and fibres are the suggested sources of carbon for biofloc production (Martinez-cordova et al., 2015). Carbon source used in the present study has a considerable amount of carbohydrate as well as fibre which together contribute about $66 \%$. The added advantage of these complex carbon sources (starch and fibre) is that it acts as a substrate for the aggregation of bacteria and helps in maintaining the organic carbon release for longer periods(Martinez-cordova et al., 2015). De-oiled oil palm kernel meal has a crude protein level of $15.5 \%$ which can act as an additional protein source for the cultured animal (if ingested directly or through biofloc). The nutritional composition of biofloc was in range as already reported by many researchers in fish as well as crustacean based biofloc technology (Ekasari et al., 2010; Megahed, 2010).

Fig.1 Specific activities of protease (unit's $\mathrm{min}^{-1} \mathrm{mg}^{-1}$ protein) and amylase (unit's min ${ }^{-1} \mathrm{mg}^{-1}$ protein) in the hepatopancreas of L. vannamei juveniles at the end of 40 days experiment

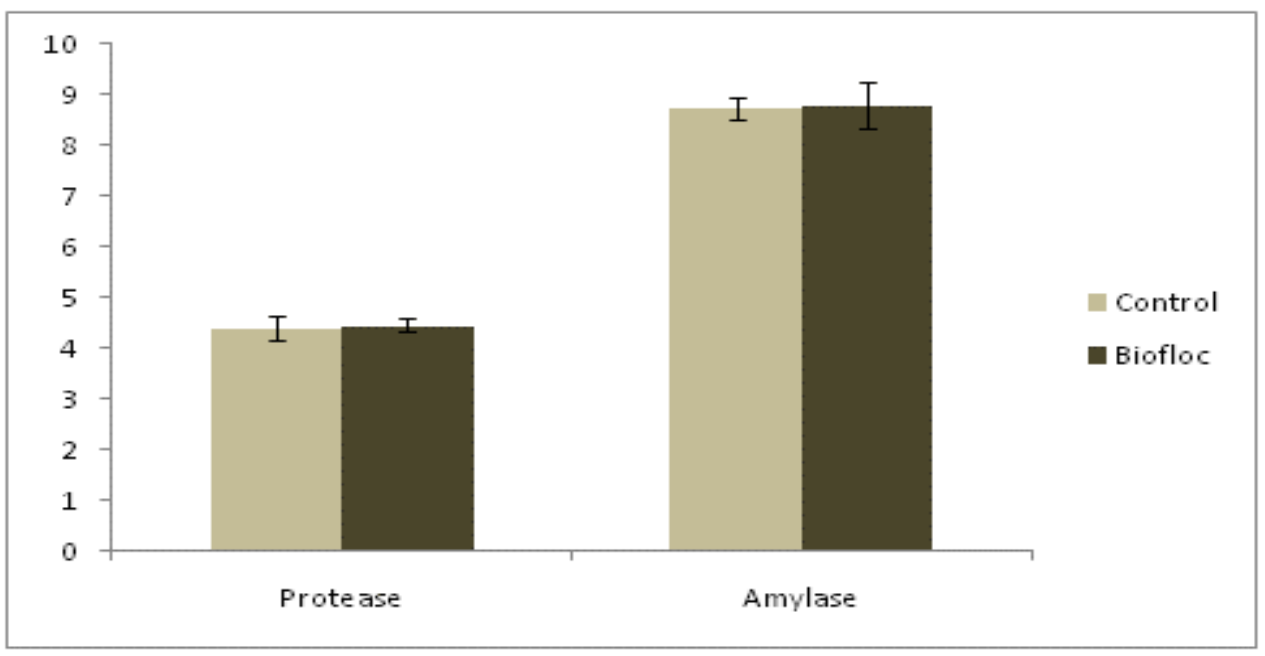


Table.1 Water quality parameters (mean \pm S.E and range) observed in the present study

\begin{tabular}{|c|c|c|c|c|c|c|c|c|}
\hline $\begin{array}{l}\text { Parameters } \\
\text { Treatments }\end{array}$ & $\begin{array}{c}\text { DO } \\
\left(\mathrm{mgL}^{-1}\right)\end{array}$ & pH & $\begin{array}{c}\text { Alkalinity } \\
\left(\mathrm{mg} \mathrm{CaCO}_{3} \mathrm{~L}^{-1}\right)\end{array}$ & $\begin{array}{c}\text { TAN } \\
\left(\text { mgL }^{-1}\right)\end{array}$ & $\begin{array}{c}\mathrm{NO}_{2}^{-} \\
\left(\mathrm{mgL}^{-1}\right)\end{array}$ & $\begin{array}{c}\mathrm{NO}_{3}^{-} \\
\left(\mathrm{mgL}^{-1}\right)\end{array}$ & $\begin{array}{c}\text { Temperature } \\
\left({ }^{\circ} \mathbf{C}\right)\end{array}$ & $\begin{array}{c}\text { Salinity } \\
\text { (ppt) }\end{array}$ \\
\hline Control & $\begin{array}{c}5.57 \pm 0.10 \\
(4.7,6.5)\end{array}$ & $\begin{array}{c}7.99 \pm 0.04^{b} \\
(7.4,8.2)\end{array}$ & $\begin{array}{c}161.90 \pm 2.14^{\mathrm{b}} \\
(140,180)\end{array}$ & $\begin{array}{c}0.27 \pm 0.04 \\
(0,0.5)\end{array}$ & $\begin{array}{c}0.19 \pm 0.03^{\mathrm{a}} \\
(0.1,0.5)\end{array}$ & $\begin{array}{c}1.37 \pm 0.08^{\mathrm{a}} \\
(1,2)\end{array}$ & $\begin{array}{c}26.57 \pm 0.13 \\
(26,28)\end{array}$ & 7 \\
\hline Biofloc & $\begin{array}{c}5.50 \pm 0.13 \\
(4.5,6.5)\end{array}$ & $\begin{array}{c}7.70 \pm 0.10^{\mathrm{a}} \\
(6.7,8.2)\end{array}$ & $\begin{array}{c}153.10 \pm 1.40^{\mathrm{a}} \\
(140,160)\end{array}$ & $\begin{array}{c}0.44 \pm 0.09 \\
(0,1.5)\end{array}$ & $\begin{array}{c}0.85 \pm 0.11^{\mathrm{b}} \\
(0.3,2)\end{array}$ & $\begin{array}{c}25.00 \pm 1.65^{b} \\
(10,40)\end{array}$ & $\begin{array}{c}26.52 \pm 0.13 \\
(26,28)\end{array}$ & 7 \\
\hline
\end{tabular}

Table.2 Proximate composition of De-oiled Oil palm kernel meal and Biofloc expressed as \% dry matter

\begin{tabular}{|l|c|c|}
\hline & $\begin{array}{c}\text { De-oiled Oil palm } \\
\text { kernel meal }\end{array}$ & Biofloc \\
\hline Crude protein & $15.58 \pm 0.36$ & $22.96 \pm 0.30$ \\
\hline Crude lipid & $6.8 \pm 0.19$ & $3.8 \pm 0.11$ \\
\hline Ash & $3.53 \pm 0.24$ & $4.7 \pm 0.19$ \\
\hline Carbohydrate & $30.29 \pm 0.35$ & $26 \pm 0.27$ \\
\hline Fibre & $35.83 \pm 0.32$ & $14 \pm 0.41$ \\
\hline
\end{tabular}

Table.3 Growth performance and feed utilization of L. vannamei juveniles at the End of 40 days experiment

\begin{tabular}{|l|c|c|}
\hline & \multicolumn{2}{|c|}{ Treatments } \\
\hline & Control & Biofloc $^{\mathrm{a}}$ \\
\hline Initial individual weight $\mathbf{( g )}$ & $0.83 \pm 0.02^{\mathrm{a}}$ & $0.81 \pm 0.02^{\mathrm{a}}$ \\
\hline Final individual weight $\mathbf{( g )}$ & $3.55 \pm 0.08^{\mathrm{a}}$ & $4.99 \pm 0.08^{\mathrm{b}}$ \\
\hline Weight gain (\%) & $329.20 \pm 7.09^{\mathrm{a}}$ & $519.05 \pm 9.52^{\mathrm{b}}$ \\
\hline SGR (\%/day) & $3.64 \pm 0.04^{\mathrm{a}}$ & $4.56 \pm 0.04^{\mathrm{b}}$ \\
\hline FCR & $1.86 \pm 0.01^{\mathrm{b}}$ & $1.61 \pm 0.02^{\mathrm{a}}$ \\
\hline FCE & $0.54 \pm 0.004^{\mathrm{a}}$ & $0.62 \pm 0.006^{\mathrm{b}}$ \\
\hline PER & $1.54 \pm 0.01^{\mathrm{a}}$ & $1.78 \pm 0.02^{\mathrm{b}}$ \\
\hline Survival (\%) & $84.67 \pm 1.45^{\mathrm{a}}$ & $88.67 \pm 0.88^{\mathrm{b}}$ \\
\hline
\end{tabular}




\section{Zootechnical performance}

In the present study, utilization of nonconventional carbon source de-oiled oil palm kernel meal had shown a significant effect on the growth performance and feed utilization of $L$. vannamei. The increase in growth performance and feed utilization of the shrimps reared in biofloc were reported by several researchers (Kuhn et al., 2010; Megahed., 2010; Emerenciano et al., 2011; Krummenauer et al., 2011; Ray et al., 2011; Emerenciano et al., 2012; Xu and Pan, 2012; Kim et al., 2014; Ray and Lotz, 2017). In addition to this, biofloc acts as a supplemental feed source which results in the better zootechnical performance (Burford et al., 2004; Kuhn et al., 2008; Megahed, 2010). The nutritional requirement of $L$. vannamei is $30-36 \%$ crude protein, 6-8\% lipid, 15-20\% carbohydrate (Zhu et al., 2010; Shahkar et al., 2014; Wang et al., 2014; Li et al., 2015). Biofloc is known to provide additional protein, lipid, vitamin and mineral for shrimp growth (Izquierdo et al., 2006; Wasielesky et al., 2006; Ju et al., 2008b).

According to Lin et al., (2007), the exogenous enzymes in the diets increase the efficiency of the digestion process. The microbes associated with biofloc are assumed to produce exogenous enzymes which help in the breakdown of proteins, carbohydrates and other nutrients into smaller units which improved the feed digestibility and absorption (Xu and Pan, 2012). The microbes in the biofloc once ingested by shrimp acts as an extracellular enzyme source and improve the digestive function. So as a supplemental feed source and external enzyme source, biofloc might have assisted in enhancing the growth performance and feed utilization in the present study. Studies reported low FCR values in the biofloc treatments which may be due to the additional contribution of the biofloc to the shrimp nutrition (Wasielesky et al., 2006). Present study recorded a survival rate of $88.67 \pm 0.88$ in the biofloc treatment which is significantly higher than control as reported in an earlier study (Mishra et al., 2008).

\section{Digestive enzyme activity}

The main site of digestion and absorption in shrimps are intestine and stomach with the help of digestive enzymes secreted by digestive gland (Dall et al., 1990). The digestive enzyme activity in hepatopancreas has not shown any significant difference. However, slight increases in protease and amylase activities were observed in biofloc treatment. A similar result was reported by $\mathrm{Xu}$ and Pan, 2012 in L. vannamei, where a slight increase in the amylase and protease activities of the biofloc treatments without any significant difference was observed. Biofloc is assumed to be cellular nutrition source due to the presence of various bioactive compounds and unknown factors (Ju et al., 2008b). Shrimps grown in biofloc are speculated to change digestive enzyme activities in response to the changes in the diet conditions (Le Moullac et al., 1996; Xu and Pan, 2012). The biofloc is presumed to enhance the production or activity of the digestive enzymes which in turn contributed to the better growth and feed utilization (Moss et al., 2001; Xu et al., 2012, 2013).

The present study explored the potential of non-conventional carbon source, de-oiled oil palm kernel meal in the biofloc development. As the research is progressing in the biofloc systems in aquaculture, the need and search for the cheaper carbon sources is increasing. Utilization of carbon sources which already have an application in others fields will not be a befitting option for aquaculture biofloc systems. Using the agro-industrial byproducts/wastes for the production of aquaculture biofloc systems can help in the 
recycling of these materials into useful, nutritious feed for the aquatic organisms. So the present study suggests that oil palm industry waste and non-conventional carbon source (de-oiled oil palm kernel meal) can be used as a potential alternative cheaper carbon source for commercial biofloc production systems.

\section{Acknowledgements}

The authors are thankful to The Director and Vice-chancellor, ICAR-CIFE for his cooperation and encouragement throughout this study.

\section{References}

Ahmad, I., A.M. Babitha Rani, A.K. Verma and Maqsood, M. 2017. Biofloc technology: an emerging avenue in aquatic animal health care and nutrition. Aquaculture International, 1-12.

AOAC 1995. Official Methods of Analysis, Association of Official Analytical Chemists, 15th edn, Washington DC.

APHA 1998. Standard methods of the examination of water.15th edn. American Public Health Association, Washington, D.C: pp. 1193.

Avnimelech, Y. 1999. Carbon / nitrogen ratio as a control element in aquaculture systems. Aquaculture. 176: 227-235.

Avnimelech, Y. 2009. Biofloc technology.A practical guide book. The World Aquaculture Society, Baton Rouge. United States. 182pp.

Avnimelech, Y. and Kochba, M. 2009. Evaluation of nitrogen uptake and excretion by tilapia in biofloc tanks, using $15 \mathrm{~N}$ tracing. Aquaculture, 287(1): 163168.

Babu, Y.M., K.R. Ramudu, S.S. Dana and Dash, G. 2013. An overview on Litopenaeus vannamei farming practices in India, current issues, problems and future perspectives. International Journal of Current Research, 5(08): 2118-2122.
Bernfeld, P. 1955. Amylase a and b. Methods in Enzymology. 1: 149-151.

Burford, M.A., P.J. Thompson, R.P. McIntosh, R.H. Bauman and Pearson, D.C. 2004. The contribution of flocculated material to shrimp (Litopenaeus vannamei) nutrition in a high-intensity, zero-exchange system. Aquaculture, 232(1): 525-537.

Caipang, C.M.A., H.X. Choo, Z. Bai, H. Huang and Lay-yag, C.M. 2015. Viability of sweet potato flour as carbon source for the production of biofloc in freshwater culture of tilapia, Oreochromis $s p$. International Aquatic Research, 7(4): 329-336.

Cohen J., T.M. Samocha, J.M. Fox and Lawrence, A.L.2005.Biosecured production of juvenile Pacific white shrimp in an intensive raceway system with limited water discharge. Aquaculture Engineering32:425-442.

Crab, R., A. Lambert, T. Defoirdt, P. Bossier and Verstraete, W. 2012.The application of bioflocs technology to protect brine shrimp (Artemia franciscana) from pathogenic Vibrio harveyi. Journal of Applied Microbiology, 109: 1643-1649.

Dall, W., B.J. Hill, P.C. Rothlisberg and Staples, D.J. 1990. The Biology of the Penaeidae Advances in Marine Biology, 27: 25-34.

De Schryver, P. and Verstraete, W. 2009. Nitrogen removal from aquaculture pond water by heterotrophic nitrogen assimilation in lab-scale sequencing batch reactors. Bioresource Technology, 100(3): 1162-1167.

De Schryver, P., R. Crab, T. Defoirdt, N. Boon and Verstraete, W. 2008. The basics of bio- flocs technology: the added value for aquaculture. Aquaculture.277 (3-4): 125-137.

Ebeling, J.M., M.B. Timmons and Bisogni, J.J. 2006.Engineering analysis of the stoichiometry of photoautotrophic, autotrophic, and heterotrophic removal of ammonia-nitrogen in aquaculture systems. Aquaculture, 257(1): 346-358. 
Ekasari, J., R. Crab and Verstraete, W. 2010. Primary nutritional content of bio-flocs cultured with different organic carbon sources and salinity. Journal of Biosciences, 17(3): 125-130.

Emerenciano, M., E.L. Ballester, R.O. Cavalli and Wasielesky, W. 2012. Biofloc technology application as a food source in a limited water exchange nursery system for pink shrimp Farfantepenaeus brasiliensis (Latreille, 1817). Aquaculture Research, 43(3): 447-457.

Emerenciano, M., E.L. Ballester, R.O. Cavalli and Wasielesky, W. 2011. Effect of biofloc technology (BFT) on the early postlarval stage of pink shrimp Farfantepenaeus paulensis: growth performance, floc composition and salinity stress tolerance. Aquaculture International, 19(5): 891-901.

Emerenciano, M., G. Gaxiola and Cuzon, G. 2013. Biofloc technology (BFT): a review for aquaculture application and animal food industry. In: Biomass Now Cultivation and Utilization (Matovic MD (ed.)). InTech, Queen's University, Belfast, Canada. pp. 301-328.

Fast, A.W. and Lester, L.J. 2013. Marine shrimp culture: principles and practices ISBN: 978-0-444-88606-4 (Vol. 23). A volume in Developments in Aquaculture and Fisheries Science, Elsevier.

Gunalan, B., P. Soundarapandian, T. Anand, A.S. Kotiya and Simon, N.T. 2014. Disease occurrence in Litopenaeus vannamei shrimp culture systems in different geographical regions of India.International Journal of Aquaculture, 4(4): 24-28.

Hari, B., B.M. Kurup, J.T. Varghese, J.W. Schrama and Verdegem, M.C.J. 2004. Effects of carbohydrate addition on production in extensive shrimp culture systems. Aquaculture, 241(1): 179-194.

Hari, B., K.B. Madhusoodana, J.T. Varghese, J.W. Schrama and Verdegem, M.C.J. 2006. The effect of carbohydrate addition on water quality and the nitrogen budget in extensive shrimp culture systems.
Aquaculture 252: 248-263.

Izquierdo, M., I. Forster, S. Divakaran, L. Conquest, O. Decamp and Tacon, A 2006. Effect of green and clear water and lipid source on survival, growth and biochemical composition of Pacific white shrimp Litopenaeus vannamei. Aquaculture Nutrition, 12(3): 192-202.

Ju, Z.Y., I. Forster, L. Conquest and Dominy, W. 2008. Enhanced growth effects on shrimp (Litopenaeus vannamei) from inclusion of whole shrimp floc or floc fractions to a formulated diet. Aquaculture Nutrition, 14(6): 533-543.

Ju, Z.Y., I. Forster, L. Conquest, W. Dominy, W.C. Kuo and David Horgen, F. 2008. Determination of microbial community structures of shrimp floc cultures by biomarkers and analysis of floc amino acid profiles. Aquaculture Research, 39(2): 118-133.

Kim, S.K., Z. Pang, H.C. Seo, Y.R. Cho, T. Samocha and Jang, I.K. 2014.Effect of bioflocs on growth and immune activity of Pacific white shrimp, Litopenaeus vannamei postlarvae. Aquaculture Research, 45(2): 362-371.

Krummenauer, D., S. Peixoto, R.O. Cavalli, L.H. Poersch and Wasielesky, W. 2011.Super intensive culture of white shrimp, Litopenaeus vannamei, in a biofloc technology system in southern Brazil at different stocking densities. Journal of the World Aquaculture Society, 42(5): 726-733.

Kuhn, D.D., A.L. Lawrence, G.D. Boardman, S. Patnaik, L. Marsh and Flick, G.J. 2010. Evaluation of two types of bioflocs derived from biological treatment of fish effluent as feed ingredients for Pacific white shrimp, Litopenaeus vannamei. Aquaculture, 303(1): 28-33.

Kuhn, D.D., G.D. Boardman, S.R. Craig, G.J. Flick and McLean, E. 2008. Use of microbial flocs generated from tilapia effluent as a nutritional supplement for shrimp, Litopenaeus vannamei, in recirculating aquaculture systems. Journal of the World Aquaculture Society, 39(1): 
72-82.

Le Moullac, G., B. Klein, D. Sellos and Van Wormhoudt, A. 1997.Adaptation of trypsin, chymotrypsin and $\alpha$-amylase to casein level and protein source in Penaeus vannamei (CrustaceaDecapoda). Journal of Experimental Marine Biology and Ecology, 208(1-2): 107-125.

Li, E., X. Wang, K. Chen, C. Xu, J.G. Qin and Chen, L. 2015. Physiological change and nutritional requirement of Pacific white shrimp Litopenaeus vannamei at low salinity. Reviews in Aquaculture. 9(1): 57-75.

Lightner, D.V., R.M. Redman, C.R. Pantoja, K.F.J. Tang, B.L. Noble, P. Schofield, L.L. Mohney, L.M. Nunan and Navarro, S.A. 2012. Historic emergence, impact and current status of shrimp pathogens in the Americas. Journal of Invertebrate Pathology. 110: 174-183.

Lin, S., K. Mai and Tan, B. 2007.Effects of exogenous enzyme supplementation in diets on growth and feed utilization in tilapia, Oreochromisniloticus x O. aureus. Aquaculture research, 38(15): 1645-1653.

Liu, Y.M., J.Z. Zhu, H.Y. Wu and Shi, D.Z. 1991. Studies on digestive enzymes and amino acids of larval and post larval stages of prawn Penaeus chinensis (O'Sbeck 1965). OceanologiaLimnologiaSinica 22: 571-574.

Martínez-Córdova, L.R., M. Emerenciano, A. Miranda-Baeza and Martínez-Porchas, M. 2015. Microbial-based systems for aquaculture of fish and shrimp: an updated review. Reviews in Aquaculture, 7(2): 131-148.

McAbee, B.J, C.L. Browdy, R.J. Rhodes and Stokes, A.D. 2003. The use of greenhouse-enclosed raceway systems for the superintensive production of pacific white shrimp Litopenaeus vannamei in the United States. Glob.Aquac. Advocate, 6: 40-43

Megahed, M.E. 2010. The effect of microbial biofloc on water quality, survival and growth of the green tiger shrimp (Penaeus semisulcatus) fed with different crude protein levels. Journal of the Arabian Aquaculture Society, 5(2): 119-142.

Mishra J.K., T.M. Samocha, S. Patnaik, M. Speed, R.L. Gandy andAli A.2008.Performance of an intensive nursery system for the Pacific white shrimp,Litopenaeus vannamei, under limited discharge condition. Aquaculture Engineering, 38:2-15.

Moss, S.M., S. Divakaran and Kim, B.G. 2001.Stimulating effects of pond water on digestive enzyme activity in the Pacific white shrimp, Litopenaeus vannamei (Boone). Aquaculture Research, 32: 125-131

Naylor, R.L. 2000.The economics of alien species invasions. In: H. Mooney, H. and R. Hobbs (Eds.), Invasive species in a changing world (241-259). Washington, D.C.: Island Press.

Newman, N., 2015. EMS (AHPNS or AHPND) Update August 2015. Research gate. Aquaintech Inc. (August).

Nielsen, S.S. 2010. Food analysis. Springer Science and Business Media, pp. 550 (ISBN 978-1-4419-1477-4.

Pan, L.Q., and Wang, K.Q. 1997. Studies on digestive enzyme activities and amino acid in the larvae of Portunus trituberculatus (Chinese). J. Fish. China, 21: 246-251.

Pearson, D. 1976. Chemical Analysis of Foods, 7th Ed. J and A Churchill, London.

Ray, A.J., and Lotz, J.M. 2017. Comparing salinities of 10, 20, and 30\% in intensive, commercial-scale biofloc shrimp (Litopenaeus vannamei) production systems. Aquaculture, 476: 29-36.

Ray, A.J., K.S. Dillon and Lotz, J.M. 2011.Water quality dynamics and shrimp (Litopenaeus vannamei) production in intensive, mesohaline culture systems with two levels of biofloc management. Aquacultural Engineering, 45(3): 127136.

Samocha, T.M.,S. M. Patnaik, A.M. Speed, J.M. Ali, R.V. Burger, Z. Almeida, M. 
Ayub, A. Harisanto, Horowitz and Brock, D.L. 2007. Use of molasses as carbon source in limited discharge nursery and grow-out systems for Litopenaeus vannamei. Aquacultural Engineering, 36:184-191.

Shahkar, E., H. Yun, G. Park, I.K. Jang, S. Kim, K. Katya and Bai, S.C. 2014.Evaluation of optimum dietary protein level for juvenile white leg shrimp (Litopenaeus vannamei). Journal of Crustacean Biology, 34(5): 552-558.

Van Wyk, P., and Scarpa, J., 1999. Water quality requirements and management. Farming marine shrimp in recirculating freshwater systems, pp.128-138.

Vinatea, L., A.O. Gálvez, C.L. Browdy, A. Stokes, J. Venero, J. Haveman, B.L Lewis, A. Lawson, A. Shuler and Leffler, J.W. 2010. Photosynthesis, water respiration and growth performance of Litopenaeus vannamei in a superintensive raceway culture with zero water exchange: interaction of water quality variables. Aquacultural Engineering, 42(1): 17-24.

Wang, X., E. Li, J.G. Qin, S. Wang, X. Chen, Y. Cai, K. Chen, Y. Hou, N. Yu, M. Zhang and $\mathrm{Du}, \mathrm{Z}$. 2014. Growth, body composition, and ammonia tolerance of juvenile white shrimp Litopenaeus vannamei fed diets containing different carbohydrate levels at low salinity. Journal of Shellfish Research, 33(2): 511-517.

Wasielesky, W., H. Atwood, A. Stokes and Browdy, C.L. 2006. Effect of natural production in a zero exchange suspended microbial floc based super-intensive culture system for white shrimp Litopenaeus vannamei. Aquaculture, 258(1): 396-403.

Xu, W.J., and Pan, L.Q., 2012. Effects of bioflocs on growth performance, digestive enzyme activity and body composition of juvenile Litopenaeus vannamei in zero-water exchange tanks manipulating $\mathrm{C} / \mathrm{N}$ ratio in feed. Aquaculture, 356: 147-152.

Xu, W.J., L.Q. Pan, D.H. Zhao and Huang, J. 2012. Preliminary investigation into the contribution of bioflocs on protein nutrition of Litopenaeus vannamei fed with different dietary protein levels in zero-water exchange culture tanks. Aquaculture, 350: 147-153.

Xu, W.J., L.Q. Pan, X.H. Sun and Huang, J. 2013. Effects of bioflocs on water quality, and survival, growth and digestive enzyme activities of Litopenaeus vannamei (Boone) in zero-water exchange culture tanks. Aquaculture Research, 44(7): 1093-1102.

Yang, S.P., and Qiu, D.Q. 2006.Water quality in the high-density shrimp culturing ponds. Fisheries Science, 9: 6-11.

Zhu, X.Z., Y.J. Liu, L.X. Tian, K.S. Mai, S.X. Zheng, Q.J. Pan, M.C. Cai, C.Q. Zheng, Q.H. Zhang and Hu, Y. 2010. Effects of dietary protein and lipid levels on growth and energy productive value of pacific white shrimp, Litopenaeus vannamei, at different salinities. Aquaculture Nutrition, 16(4): 392-399.

\section{How to cite this article:}

Karthireddy Syamala, W.S. Lakra, N.K. Chadha, N.P. Sahu and Pani Prasad, K. 2017. Effect of DeOiled Oil Palm Kernel Meal Based Biofloc System on Growth and Digestive Enzyme Activity of Pacific White Shrimp, Litopenaeus Vannamei. Int.J.Curr.Microbiol.App.Sci. 6(6): 1806-1816. doi: https://doi.org/10.20546/ijcmas.2017.606.210 